\title{
A SOCIO-ECONOMIC ANALYSIS OF RURALITY IN ITALY USING A PLS-SEM APPROACH
}

\author{
N. Galluzzo* \\ Association of Geographical and Economic Studies in Rural Areas, Rieti, Italy
}

\begin{abstract}
In Italy there has been a significant decrease of farms which undertake an important role in rural environmental protection and in the socio-economic development in rural areas.

PURPOSE: The aim of this paper was to assess by a quantitative methodology the index of rurality in Italian farms part of the FADN dataset since 2004 to 2016.

METHODS: The methodology has used the Partial Least Square Structural Equation Modelling aimed at estimating the notable cause-effect relationships among all economic variables.

RESULTS: Findings have pointed out as the variable financial subsidies allocated by the CAP and the farm specialization have influenced the index of rurality.

CONCLUSIONS: For the future development of rural areas it is important to support financially rural areas; in particular subsidies should be addressed to less favored areas in order to reduce their socioeconomic marginalization.
\end{abstract}

Key words: rural development, Common Agricultural Policy, farm specialization, LFA subsidies, rural areas.

\section{INTRODUCTION}

Since the late1950s there has been a significant emigration from the Italian countryside due to a surprisingly arising phenomenon of industrialization in the north of the country which has attracted lots of people in some rich urban areas and in other European countries such as Swiss, Germany and Belgium. In 1980s a relentless growth in the tertiary sector has further strengthened the out emigration from the countryside even if recently the rural space has regained a positive role in the counter urbanization process $(1,2)$ corroborating the hypothesis of an evolution of the rurality in Italy as argued by some authors who have divided it into three phases of growth (3). In the recent years, the European countryside has played a positive and notable role in increasing job opportunities in particular during the economic recession time in 2008-2010 (4-8).

\footnotetext{
*Correspondence to: Nicola Galluzzo, Association of Geographical and Economic Studies in Rural Areas, Via Salaria per L'Aquila 76 scala A, Rieti,Italy,email:asgear@libero.it
}

In general, the duality between rural and urban areas is arisen in the recent decades considering rural areas as less favored territories with lots of socio-economic unbalances and several discomforts. By contrast, some authors have pointed out an inappropriate definition pinpointed rural areas as less developed territories $(9,10)$. These latter authors doing studies in lots of Italian regions have suggested several proposals to the policy makers aimed at reducing and partially solving the main downsides linked to the development in rural areas. The Cork conference for the rural development in 1996 and the recent one hold in 2016 has well defined the noteworthy strategies for the European Union proposing to the national authorities' challenges and intervention measures aimed in promoting an integrated development of rural areas and an adequate environmental protection. Rural areas in all European countries are pivotal in protecting the environment and the population in a perspective of a kaleidoscopically and integrated multifunctionality and socioeconomic development (11-16). This has 
implied an integrated approach in the process of rural development addressing the attention of policy makers towards a new function infarm and off-farm codified and non-codified activities $(17,18)$.

A quantitative approach and other empirical studies have been used in order to estimate some indexes of rurality even if rural areas are considered as a disadvantaged space with lower levels of accessibility than urban ones (10) with a level of poverty assessed in different rural areas which is higher than in urban territories on the light of the global growth (19); hence, strategies tailored for the rural development growth have to take into consideration as investigated in other European countries measures able to financially support the transition phase from a productivist model to a post-productivist model of production (20) which has been sometimes criticized by other author (11-13). The purpose of the transition from a productivist model to a post productivist one has been focused in getting better the quality of live in the countryside instead of increasing the quantity of agricultural productions (21). As a consequence of the socio-economic transformation in the countryside and in urban territories after the industrialization and recently by the post-industrialization phase of growth the relationships among rural and urban territories are radically changed (22) with different phases of growth both over the time and also in different areas of investigation.

In literature review lots of studies and researches have investigated in depth the rurality with the purpose to propose a quantitative assessment of it $(1,5,6,23-28)$. Many scholars have evaluated which socioeconomic variables have acted towards the rurality $(5,6,23,25,29)$. Roughly speaking, the concept of rurality is based predominately by different variables such as the density of population, the links among people in a perspective of generating a social network and the distance from urban centers (30).

The starting point in the approach aimed at discriminating between rural and urban space is the density of population $(3,22)$ even if comparing different approaches used by the European Union and other international institutions such as Eurostat and OCSE the density of population is largely changeable and an integrated and multidimensional approach is pivotal in estimating the rurality (22).
Halfacree in 2002 has investigated in different European countries the concept of rurality and its own meaning even if, over the time critical issues in rural areas are increased and only in the early 1990s, following a trajectory of development in less favoured areas began in the middle 1970s, the European Union has financially supported the rural space ratified recently by the Cork 2.0 conference with a relocation of financial resources from the first to the second pillar of the Common Agricultural Policy aimed at supporting the rural development $(31,32)$. In rural areas it is important to strengthen by the Leader approach and other initiatives of the rural development financed by the European Union throughout the second pillar of the Common Agricultural Policy able to stimulate an endogenous and integrated growth in rural areas which is able also to create pilot initiatives in other neighbouring areas (33).

\section{AIM OF THE PAPER}

The main purpose of this research has been to investigate by a quantitative approach which socio-economic variables have acted on the rurality in Italy over the time 2004-2016 and the main correlations among variables with the aim to build an index of rurality. The main research question was: is it possible to estimate the rurality by a quantitive approach? Secondly: what is the main cause-effect relationship among socio-economic variables influencing the index of rurality?

\section{METHODOLOGY}

Many researchers have investigated in different countries the rurality aimed at defining a quantitative index and which socioeconomics variables have been involved in it (1, 5, 6, 23-29). Recently Jacquet et al in 2017 have investigated throughout a quantitative approach as well in a nation of the United States of America rural areas four different measures of rurality considering some socioeconomic variables tightly linked to the rural space.

Harsh is the theoretical concept able to explain in a univocal definition the concepts of rurality because of lots of variables are involved in it $(24,34)$. A quantitative index aimed at assessing the rurality and the cause-effect relationships is pivotal in estimating the impact of financial measures and socio-political strategies in favour of rural territories (23-25, 35-37). According to these authors the index of rurality has been set up using exogenous socio- 
economic variables able to define in lots of European countries which variables have acted on the growth of rural areas. Many authors have pointed out as the assessment of rurality by a quantitative approach as partially investigated the cause-effect relationships (23$25,35-37)$

One of the main issues in this research has been to define a source of homogenous data over the time of investigation in a sample of Italian farms. The source of data has been extrapolated by the dataset Farm Accountancy Data Network published by the European Union since 2004 to 2016. In order to investigate the impact of the Common Agricultural Policy to farmers the European Union has set up an annual survey called Farm Accountancy Data Network (FADN) in farms able to have got a well define level of income and usable agricultural areas. It is a complete source of economic data and information fundamental in investigating in depth of the impact of the Common Agricultural Policy towards European farmers with the aim to propose some changes in the structural policy in favour of the primary sector.

The estimation of cause-effect relationships in a small sample of dataset and a scarcity of codified model in literature using the structural equation modelling (SEM) has implied to employ a non-parametric approach; hence, the Partial Last Square Structural Equation Modelling approach (PLS-SEM) seems to fit well to the aim of the study, the features of socio-economic variables used during the analysis and to the theoretical framework proposed by different authors $(6,38-40)$. In fact, the non-parametric model PLS-SEM needs of not restrictive underlying assumptions compared to the SEM which has in literature a codified framework of study, specific implications and basic assumptions (39). The Partial Last Square Structural Equation Modelling is particularly adequate to estimate a modest sample size of investigation units made by several heterogeneous indicators without any a priori model specifications (6, 39, 41, 42). The PLS-SEM is an iterative methodology estimating the internal, external correlations and values in latent variables stratifying them in several blocks of variables which alternate simple and multiple regressions $(38,39,41,43)$. The estimation of the PLS-SEM model has used the software Smart-PLS version 3.2.7 (44). In function of the direction of the arrows from or to the latent variable there is formative or reflective measurement model $(38-42,45)$.

\section{RESULTS AND DISCUSSION}

Findings assessed in all Italian regions part of the FADN dataset have pointed out as farms have a usable agricultural area in average close to 18 hectares with notable fluctuations in function of the farming specialization and the region (Table 1). In fact, in many Italian regions characterized by mountainous and hilly areas, the usable agricultural surface is modest with a predominant diffusion of permanent crops such as sown-pasture. Modest has been the level of labour input in farms with a poor level of net investments which in average have been close to 5,000 euro and a farm net income equates to 25,000 euro per farm.

Table 1. Main features in the inner model (Source: author's elaboration on data FADN published on the website http://ec.europa.eu/agriculture/rica/database/database_en.cfm)

\begin{tabular}{lccc}
\hline Endogenous Variable & rho & Composite Reliability $(\mathbf{C R})$ & Average Variance Extracted \\
\hline CAP & 0.743 & 0.749 & 0.378 \\
ECONOMIC ASPECTS & 0.765 & 0.813 & 0.688 \\
INPUT & 0.895 & 0.888 & 0.543 \\
RURALITY & 1.000 & - & - \\
SPECIALIZATION & 0.486 & 0.509 & 0.193 \\
\hline
\end{tabular}

The total amount of financial subsidies allocated by the Common Agricultural Policy has been in average value close to 7,000 euro for each farm with the maximum value equal to 22,546 euro and the lowest value close to 525 euro. In general, the subsidies on crops have been higher than subsidies allocated to livestock with a notable incidence of environmental payments disbursed by the European Union. The decoupled payments which are the preponderant part of the financial subsidies allocated by the first pillar of the CAP have been in average close to 4,300 euro per farms; financial aids in favor of farms 
located in stayed behind rural areas have been modest with an average value close to 600 euro and significant has been the financial subsidies allocated by the second pillar of the Common Agricultural Policy aimed at stimulating the diversification in rural areas.

The variable total output produced by the Italian farms belonging to the FADN dataset correlates directly to the labour input hence, the higher is the level of output produced in farms the higher is the level of labour input in farms (Figure 1). A direct correlation also has

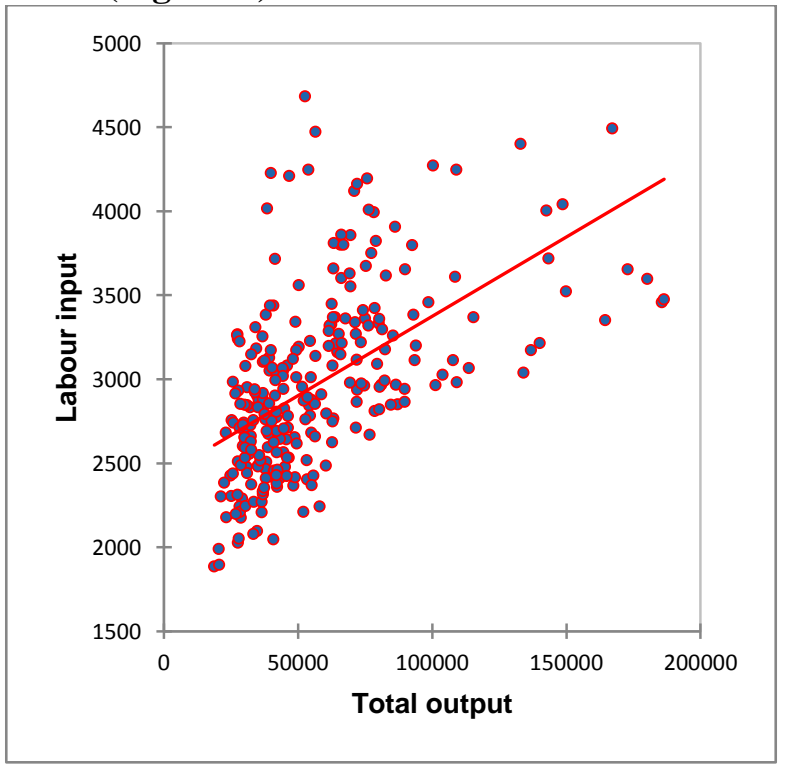

been found between the variable total output and specific costs such as fertilizers, cost for seeds and cost for livestock feedings (Figure 1). The values of $R^{2}$ in the variables economic aspects and rurality have pointed out as more than $60 \%$ of the variance is explained by the model; by contrast, only $47 \%$ of the variance has been explained by the endogenous variable CAP. The values of $R^{2}$ and adjusted $R^{2}$ have been the same hence, an increase of items did not influence the model.

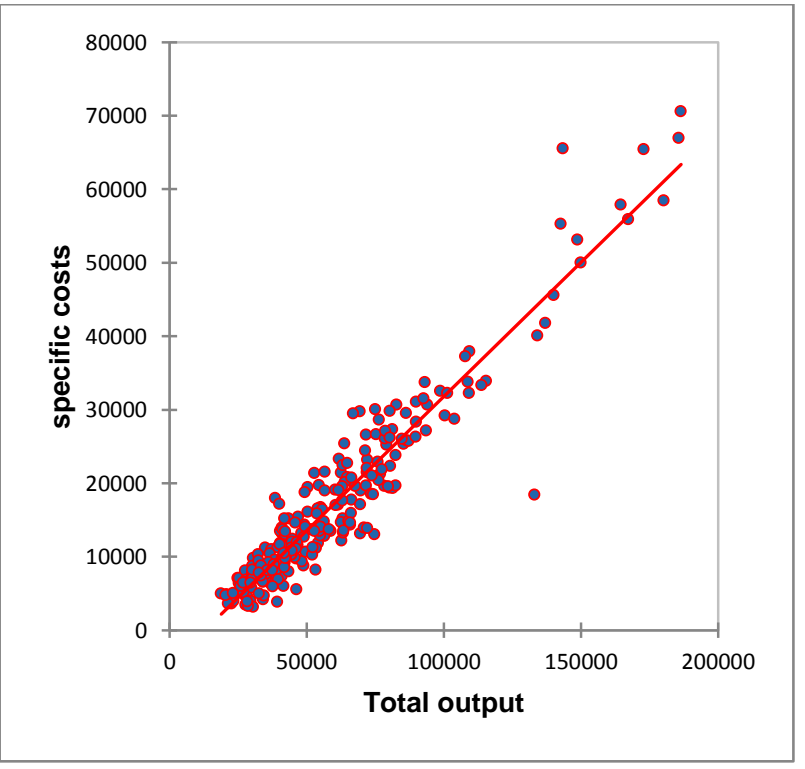

Figure 1. Main correlations among the total output and other economic variables in Italian farms part of FADN dataset (Source: author's elaboration on data FADN published on the website http://ec.europa.eu/agriculture/rica/database/database_en.cfm)

The endogenous variable specialization made by items with a nexus to the different typologies of agricultural areas stratified in function of the crop specialization has had a direct effect on the rurality and on the endogenous variable CAP specialization made by financial subsides allocated by the Common Agricultural Policy (Figure 2). An indirect effect has been assessed between the endogenous variable economic aspects towards the variable rurality. On the variable rurality in the reflexive approach the items LFA financial subsidies has had a positive impact with a level of $p$ value lower than 5\%. By contrast, farm net income and the endowment of land capital have had the highest impacts towards the rurality with $\mathrm{p}$ values lower than 0.01. All items in endogenous variable input have been positively and directly correlated to it with levels of significance lower than 0.01 . The endogenous variable specialization of farms has been directly correlated to the variables CAP and economic aspect and in particular towards the CAP it has had the more significant and notable cause-effect. The items surface cultivated with permanent crops and vineyards did not have any effect on the endogenous variable specialization. Summing up the level of investments in farms, the farm's specialization, the financial subsidies allocated by the Common Agricultural Policy and the input has had a direct effect on the rurality. However, only the endogenous variable economic aspect has not had any relationships and significant effect to the rurality. 


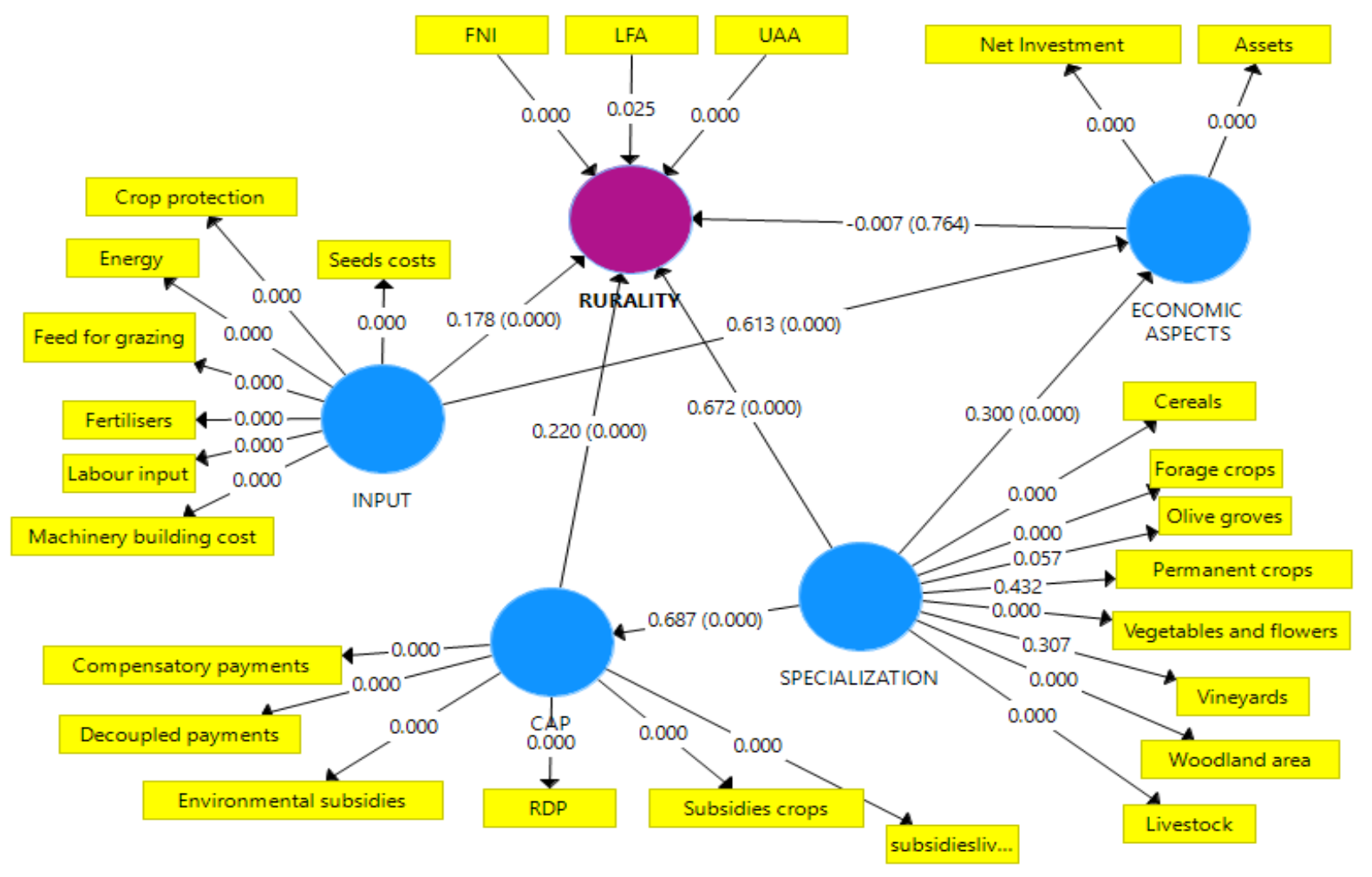

Figure 2. PLS-SEM findings expressed as p values in all items and endogenous variables assessed in all investigated Italian farms part of FADN dataset (Source: author's elaboration on data FADN published on the website http://ec.europa.eu/agriculture/rica/database/database_en.cfm)

The values of rho have been very high in all endogenous variables with the exception of the specialization which has been under the threshold of 0.70 (Table 1); in the same time the Composite Reliability (CR) has been above the optimal value equal to 0.70 in all investigated endogenous variables with the exception of the variable specialization which has also had the lowest value in the Average Variance Extracted (AVE).

The f-square value has been estimated in this model. It describes how large a proportion of unexplained variance is accounted for by the $\mathrm{R}^{2}$ change in the model $(39,40)$. Table 2 showed the effect of latent variables with notable values above the threshold of 0.35 proposed by Hair et al. in 2016 in the variables economic aspects and input, CAP and specialization, rurality and specialization; the worst result or rather no effect has been found between the variables rurality and economic aspects and a modest effect between the variables rurality and input and between the variables specialization and economic aspects. The values of predictive effects expressed as $\mathrm{Q}^{2}$ have pointed out as all endogenous variables have been above the threshold equal to $0(39,40)$ pointing out with the exception of the variable specialization as all variables have had a predictive relevance in the endogenous model and in particular considering the endogenous variable input (Table 3).

Table 2. Values of $f^{2}$ in all endogenous variables (Source: author's elaboration on data FADN published on the website http://ec.europa.eu/agriculture/rica/database/database_en.cfm)

\begin{tabular}{l|ccccc}
\hline & CAP & $\begin{array}{c}\text { ECONOMIC } \\
\text { ASPECTS }\end{array}$ & INPUT & RURALITY & SPECIALIZATION \\
\hline CAP & & - & - & 0.281 & - \\
ECONOMIC & - & & - & 0.000 & - \\
ASPECTS & - & 0.759 & & 0.124 & - \\
INPUT & - & - & - & & - \\
RURALITY & 0.896 & 0.182 & - & 0.901 & \\
SPECIALIZATION & 0.896 &
\end{tabular}


Table 3. Results of predictive effects as $Q^{2}$ in all endogenous variables investigated in the PLS-SEM model (Source: author's elaboration on data FADN published on the website http://ec.europa.eu/agriculture/rica/database/database_en.cfm)

\begin{tabular}{|c|c|}
\hline Endogenous variable & $\mathrm{Q}^{2}(=1-\mathrm{SSE} / \mathrm{SSO})$ \\
\hline CAP & 0.185 \\
\hline ECONOMIC ASPECTS & 0.165 \\
\hline INPUT & 0.407 \\
\hline RURALITY & 0.158 \\
\hline SPECIALIZATION & 0.026 \\
\hline
\end{tabular}

\section{CONCLUSIONS}

The PLS-SEM is a good opportunity in investigating the cause-effect relationships in a field of investigation such as the assessment of a rurality index not so common in literature. Farm net income and the level of land capital endowment are directly linked to the rurality which also has been influenced by the level of inputs, financial subsidies allocated by the $\mathrm{CAP}$ and by the level of specialization in terms of crops or animal in farms. Positive has been the role of financial subsidies allocated by the Common Agricultural Policy and in particular by the item made by aids and payments in favour of disadvantaged rural areas even if the land capital and the farm net income are two of the predominant items aging directly on the rurality in all Italian farms part of FADN dataset.

Summing up, positive has been the role of items correlated to the financial subsidies allocated by the European Union in order to support the rural development and farmer's income as the indirect payments allocated towards them.

For the future it is important to consider a different allocation of financial resources from the first pillar of the CAP to the second one in particular in mountainous and hilly areas where are located small farms which need of less favoured areas financial supports, which are modest to ensure the remaining in small rural villages scattered in mountainous areas at risk of environmental degradation, rural depopulation and socio-economic marginalization. However, it is important by the second pillar of the Common Agricultural Policy to stimulate the introduction of new technologies in farms able to reduce the cost and in turn increasing the level of net investments aimed at getting better the index of rurality. In conclusion, it is opportune to observe as the level of farm's specialization has acted predominately towards the rurality instead economic aspects have had no effect towards the rurality in Italian farms.

\section{REFERENCES}

1. Galluzzo, N., A preliminary Quantitative Analysis of Rural Development in Romania Using the PLS-SEM. Albanian j. agric. sci., 17(3): 125-133, 2018a.

2. Galluzzo, N., The impact of the common agricultural policy on the agritourism growth in Italy. Bulgarian Journal of Agricultural Science, 23(5), 698-703, 2017a.

3. Scocco, L., Agricoltura e ruralità nello sviluppo economico delle Marche. evoluzione storica ed evidenze empiriche. Collana Tesi on line. Retrieved from: http://www.associazionebartola.it/pubblicaz ioni/raccolta_tesi/scocco.pdf.

4. Westhoek, H. J., Van den Berg, M., and Bakkes, J. A., Scenario development to explore the future of Europe's rural areas. Agriculture, ecosystems \& environment, 114(1):7-20, 2006.

5. Galluzzo, N., A preliminary quantitative analysis of rurality in Romania and the impact of Common Agricultural Policy subsidies. Review of Agricultural and Applied Economics, 21(2):128-135, $2018 \mathrm{~b}$.

6. Galluzzo, N., An analysis of rurality index in Romanian countryside by a quantitative approach. Trakia Journal of Sciences, 16(2): 134-139, 2018c.

7. Galluzzo, N., Agriturismo e distretti per la valorizzazione delle aree rurali: aspetti generali e applicativi su alcuni casi di studio, Aracne editrice, Roma, 2009.

8. Galluzzo, N., Ruolo e funzione socioeconomica dell'agricoltura Italiana: per la salvaguardia delle aree rurali, Aracne editrice, Roma, 2010.

9. Balestrieri, M., Rurality and competitiveness. Some observations on the local area: The case of the Sardinian Region. International Journal of Rural Management, 10(2): 173-197, 2014. 
GALLUZZO N.

10.Caschili, S., De Montis, A., and Trogu, D., Accessibility and rurality indicators for regional development". Computers, Environment and Urban Systems, 49: 98114, 2015.

11.Wilson, G., Multifunctional 'quality'and rural community resilience. Transactions of the Institute of British Geographers, 35(3): 364-381, 2010.

12.Wilson, G.A., From productivism to postproductivism... and back again? Exploring the (un) changed natural and mental landscapes of European agriculture. Transactions of the institute of British Geographers, 26(1): 77-102, 2010.

13.Wilson, G.A., The spatiality of multifunctional agriculture: A human geography perspective. Geoforum, 40(2): 269-280, 2009.

14.Marsden, T., and Sonnino, R., Rural development and the regional state: Denying multifunctional agriculture in the UK. Journal of Rural Studies, 24(4): 422431, 2008.

15.Borrelli, I.P., Territorial sustainability and multifunctional agriculture: A case study. Agriculture and agricultural science procedia, 8: 467-474, 2016.

16.Casini, L., Contini, C. and Romano, C., Paths to developing multifunctional agriculture: insights for rural development policies". Int. J. Agricultural Resources, Governance and Ecology, 9(3-4): 185-203, 2012.

17.Van der Ploeg J.D. and Roep D., Multifunctionality and rural development: the actual situation in Europe. In: G. van Huylenbroeck and G. Durand (eds): Multifunctional Agriculture; $A$ new paradigm for European Agriculture and Rural Development. Ashgate, England, pp 37- 53, 2003.

18. Van der Ploeg, J. D., Long, A., and Banks, J. Living countrysides. Rural development processes in Europe: The state of the art. Elsevier, New York, 2002.

19.Laborde Debucquet, D. and Martin, W., Implication of the global slowdown for rural poverty. Agricultural economics, 49(3): 325-338, 2018.

20.Ilbery, B.W., Geography of rural change. Routledge, United Kingdom, 1998.

21.Cannarella, C., Rurality and rural development in post communist European countries. New Medit, 2(1): 43-49, 2003.

22.Brown, D. L., and Cromartie, J. B., The nature of rurality in postindustrial society. New forms of urbanization: Beyond the urban-rural dichotomy. Paper presented at conference 'New Forms of Urbanization: Conceptualizing and Measuring Human Settlement in the Twenty-first Century', Bellagio, Italy, 11-15 March 2002.

23.Cloke, P.J., An index of rurality for England and Wales". Regional Studies, 11(1): 31-46, 1979.

24.Cloke, P., Conceptualizing rurality. In: Cloke P., T., Marsden and P. Mooney (eds), Handbook of rural studies. SAGE publications Ltd., California, pp 18-28, 2006.

25.Cloke, P. and G. Edwards, Rurality in England and Wales 1981: a replication of the 1971 index. Regional Studies, 20(4): 289-306, 1986.

26.Harrington, V., and O'Donoghue, D., Rurality in England and Wales 1991: a replication and extension of the 1981 rurality index". Sociologia Ruralis, 38(2): 178-203, 1998.

27.Halfacree, K., Rethinking 'rurality. New forms of urbanization: Beyond the urbanrural dichotomy. Paper presented at conference: New Forms of Urbanization: Conceptualizing and Measuring Human Settlement in the Twenty-first Century, Bellagio, Italy, 11-15 March 2002.

28.Halfacree, K., Rural space: constructing a three-fold architecture. In: Cloke, P., Marsden, T., \& Mooney, P. (eds.). Handbook of rural studies. SAGE, California, pp 44-62, 2006.

29.Gilbert, J., Rural theory: the grounding of rural sociology. Rural sociology, 47(4): 609-655, 1982.

30.Jaquet, J.B., Guthrie E., and Jackson, H., Swept out: measuring rurality and migration intentions on the upper great plains. Rural sociology, 82(4): 601-627, 2017.

31.Sotte, F., Quante sono le imprese agricole in Italia. AgriRegioniEuropa (Are), 2(5): 12-16, 2006.

32.Sotte, F., Esposti, R., and Giachini, D., The evolution of rurality in the experience of the "Third Italy". Paper presented at workshop European governance and the problems of peripheral countries, 12-13 July, 2012, Vienna.

33.Doria, L., Reho, M., and Vettoretto, L., Opportunities and tensions of endogenous rural development indications from the implementation of LEADER in Italy. Paper presented at Conference Reinventing Regions in the Global Economy, Pisa, Italy, 2003. 
34.Woods, M., Performing rurality and practising rural geography. Progress in Human Geography, 34(6): 835-846, 2010.

35.Kendall, M., Multivariate analysis. Charles Griffin \& Co. Ltd, London, 1975.

36.Ocaña-Riola, R., and Sánchez-Cantalejo, C., Rurality index for small areas in Spain. Social Indicators Research, 73 (2): 247266, 2005.

37.Prieto-Lara, E., and Ocaña-Riola, R., Updating rurality index for small areas in Spain. Social Indicators Research, 95(2): 267, 2010.

38.Tenenhaus, M., Vinzi, V.E., Chatelin, Y.M., and Lauro, C., PLS path modeling. Computational statistics \& data analysis, 48(1): 159-205, 2005.

39.Hair, J.F., G.T.M., Hult, C., Ringle and M. Sarstedt, A primer on partial least squares structural equation modeling (PLS-SEM). SAGE Publications, California, 2016.

40.Hair, J.F., M., Sarstedt, M., C.M, Ringle and S.P., Gudergan, Advanced issues in partial least squares structural equation modeling. SAGE Publications, California, 2017
GALLUZZO N.

41.Wong, K.K.K., Partial least squares structural equation modeling (PLS-SEM) techniques using SmartPLS. Marketing Bulletin, 24 (1): 1-32, 2013.

42.Awang, Z., Afthanorhan, W.M.A and Asri, M.A.M., Parametric and non-parametric approach in structural equation modeling (SEM): the application of bootstrapping. Modern Applied Science, 9(9): 58-67, 2015

43. Vinzi, V.E., Trinchera, L., and Amato, S., PLS path modeling: from foundations to recent developments and open issues for model assessment and improvement. In: Vinzi, V.E., W.W, Chin, J., Henseler and H. Wang (eds): Handbook of partial least squares, Springer, Berlin Heidelberg, pp 47-82, 2010.

44.Ringle, C.M., Wende, S., and Becker, J.M., SmartPLS 3. Bönningstedt: SmartPLS. Retrieved from http://www.smartpls.com,

45.Gye-Soo, K., Partial Least Squares Structural Equation Modeling (PLS-SEM): An application in Customer Satisfaction Research". International Journal of $u$-and e-Service, Science and Technology, 9 (4): 61-68, 2016. 